Murawska A., Poziom życia w krajach Europy i Unii Europejskiej na podstawie Actual Indywidual Consumption per capita, „Ekonomia i Prawo”, Polszakiewicz B., Boehlke J. (red.), Tom XII, nr 3/2013, ss. 399-411. DOI: http://dx.doi.org/10.12775/EiP.2013.030

\title{
POZIOM ŻYCIA \\ W KRAJACH EUROPY I UNII EUROPEJSKIEJ NA PODSTAWIE ACTUAL INDYWIDUAL CONSUMPTION PER CAPITA
}

\section{STRESZCZENIE}

Zagadnienia związane $\mathrm{z}$ poziomem życia ludności stanowią kluczowe aspekty w polityce regionalnej oraz strategiach rozwoju społecznego. Poziom życia jest bliskoznacznym pojęciem związanym $\mathrm{z}$ warunkami bytu, jakością życia i dobrobytem. Od wielu lat za podstawową miarę poziomu życia uznawano PKB per capita. W 2012 roku Eurostat opublikował nową alternatywną miarę poziomu życia, którym jest faktyczne spożycie indywidualne per capita wyrażone $\mathrm{w}$ tzw. standardach siły nabywczej. W opracowaniu przedstawiono poziom życia ludności oraz jego przestrzenne zróżnicowanie w krajach Europy i Unii Europejskiej. Celem opracowania było przedstawienie różnic w poziomie życia w zależności od zastosowanego wskaźnika, a mianowicie tradycyjnego PKB per capita oraz nowego AIC per capita.

* Anna Murawska, Uniwersytet Technologiczno-Przyrodniczy im. Jana i Jędrzeja Śniadeckich w Bydgoszczy, Wydział Zarządzania, Katedra Ekonomii i Prawa Gospodarczego, tel.: +48508335 775, e-mail: anna.murawska@utp.edu.pl.

$\diamond$ Artykuł dofinansowany przez Katedrę Ekonomii i Prawa Gospodarczego na Wydziale Zarządzania Uniwersytetu Technologiczno-Przyrodniczego w ramach badań statutowych nr 24/2011. 
Słowa kluczowe: poziom życia, produkt krajowy brutto, faktyczne spożycie indywidualne, Europa, Unia Europejska, zróżnicowanie

Klasyfikacja JEL: O47, O11, I31

\title{
STANDARD OF LIVING IN THE COUNTRIES OF EUROPE AND THE EUROPEAN UNION ON THE BASIS OF ACTUAL INDIVIDUAL CONSUMPTION PER CAPITA
}

\author{
SUMMARY
}

Issues related to the standard of living are key aspects of regional policy and social development strategies. The standard of living is synonymous with the terms being, quality of life and well-being. For many years, the basic measure of the standard of living was GDP per capita. In 2012, Eurostat published a new alternative measure standard of living, which is the actual individual consumption per capita, expressed in purchasing power standards. The article presents the standard of living of the population and its spatial variation in the countries of Europe and the European Union. The aim of the study was to show the differences in standards of living, depending on the index used, namely the traditional GDP per capita, and the new AIC per capita.

Keywords: standard of living, gross domestic product, actual individual consumption, Europe, European Union, diversity

JEL Classification: O47, O11, I31

\section{WSTĘP}

Zagadnienia dotyczące poziomu życia wzbudzają duże zainteresowanie, a jednocześnie dużo kontrowersji. W głównej mierze jest to spowodowane tym, że poziom życia ma charakter interdyscyplinarny. Jest to kategoria zarówno społeczna, jak i ekonomiczna, która jest szeroka i wieloaspektowa, a zagadnienia $\mathrm{z}$ nią związane stanowią przedmiot zainteresowania między innymi ekonomistów, polityków, demografów oraz socjologów. W literaturze ekonomicznej, w najszerszym tego słowa znaczeniu, pojęcia „poziom życia” używa się podczas badania poziomu, struktury i uwarunkowań konsumpcji1.

Złożoność, wieloaspektowość i wieloelementowość poziomu życia powoduje, że można tę kategorię badać różnymi metodami. Należy jednak stwier-

${ }^{1}$ Porównaj: J. Kramer, Przestrzenna struktura konsumpcji w Polsce, PWN, Warszawa 1980, s. 28. 
dzić, że badanie poziomu życia nie jest łatwe w realizacji, gdyż pomimo wielu prób nie wypracowano dotychczas jednej standardowej metody badań, a po drugie wskaźniki opisujące poziom życia charakteryzują się dużą wieloznacznością i zróżnicowaniem² ${ }^{2}$.

W literaturze ekonomicznej dotyczącej badania poziomu życia ludności lub gospodarstw domowych spotyka się wiele mierników, wskaźników lub metod pomiaru poziomu życia. Wśród nich wymienia się globalną wielkość spożycia bieżącego przypadającego na jednego mieszkańca, spożycie rozszerzone, wskaźniki oparte na dochodach i wydatkach gospodarstw domowych, wskaźniki wyszczególnione na podstawie produktu krajowego brutto, mierniki przeciętnego dalszego trwania życia, Wskaźnik Rozwoju Społecznego (HDI) ${ }^{3}$. Do najbardziej popularnych zaliczyć można metodę dystansową (genewską) oraz różne odmiany metod taksonomicznych i analizy czynnikowej, umożliwiające m.in. konstrukcję syntetycznego miernika poziomu życia na bazie dużej ilości wyjściowych mierników szczegółowych ${ }^{4}$.

Spośród powyżej wymienionych miar poziomu życia tradycyjnym i najbardziej popularnym wskaźnikiem zwłaszcza w zakresie porównań międzynarodowych jest wielkość produktu krajowego brutto w przeliczeniu na jednego mieszkańca kraju lub regionu ${ }^{5}$. Według Cz. Bywalca i L. Rudnickiego wzrost poziomu życia, a tym samym poziomu zaspokajania potrzeb będzie następował wówczas, gdy wzrośnie PKB, a wraz z nim fundusz spożycia w przeliczeniu na jednego mieszkańca. I dopiero taki rozwój gospodarczy jest rozwojem realnym, podnoszącym dobrobyt, korzystnie odczuwalnym przez społeczeństwo, a przynajmniej znaczną jego część ${ }^{\text {. }}$

Biorąc powyższe przesłanki pod uwagę, wyznaczono sobie za cel artykułu porównanie dwóch miar poziomu życia, produktu krajowego brutto (Gross Domestic Product per capita) oraz faktycznego spożycia indywidualnego przypadającego na jednego mieszkańca (Actual Indywidual Consumption per capita). Analiz porównawczych dokonano w latach 1995-2011 dla krajów Europy, Unii Europejskiej oraz zaprezentowano pozycję Polski w rankingu krajów.

2 A. Murawska, Rozwój spoteczno-ekonomiczny a poziom życia w gospodarstwach domowych w Polsce, praca doktorska, SGGW, Warszawa (maszynopis niepublikowany), 2009, s. 47.

3 Ibidem, s. 51-55.

${ }^{4}$ J. Narkiewicz, Regionalne zróżnicowanie poziomu życia ludności, „Wiadomości Statystyczne”, nr 12, 1996, s. 76.

${ }^{5}$ K. Gutkowska, A. Murawska, Regionalne zróżnicowanie poziomu i jakości życia Polaków, „Handel Wewnętrzny”, Konsumpcja a rozwoój regionów, IBRKiK, Warszawa, styczeń-luty 2011, s. 91 .

${ }^{6}$ Cz. Bywalec, L. Rudnicki, Konsumpcja, PWE, Warszawa 2002, s. 87. 


\section{POZIOM ŻYCIA \\ W KRAJACH UNII EUROPEJSKIEJ NA PODSTAWIE GDP PER CAPITA}

W badaniach porównawczych wskaźnikiem najczęściej wykorzystywanym do oceny poziomu rozwoju gospodarczego i poziomu życia ludności jest produkt krajowy brutto (Gross Domestic Product per capita). GDP jest jednym $\mathrm{z}$ mierników dochodu narodowego stosowanym $\mathrm{w}$ rachunkach narodowych i przedstawia zagregowaną wartość dóbr i usług finalnych wytworzonych na terenie danego kraju w określonej jednostce czasu.

Przy określaniu produktu krajowego brutto kryterium geograficzne jest jedyne i rozstrzygające, gdyż nie ma znaczenia pochodzenie kapitału, własność przedsiębiorstw czy inne istotne aspekty. Czyste GDP może być wyznacznikiem poziomu rozwoju gospodarczego kraju lub regionu. $Z$ kolei GDP per capita uznawany jest za miarę dobrobytu i poziomu życia ludności.

$\mathrm{W}$ ostatnich latach $\mathrm{w}$ krajach europejskich można zaobserwować dynamiczny wzrost przychodu wypracowanego przez producentów w danym kraju. Wielkość GDP per capita obliczona według parytetu siły nabywczej ${ }^{7}$ od 2000 r. dynamicznie wzrastała we wszystkich krajach europejskich, ponad pięciokrotnie w Rumunii oraz czterokrotnie w Bułgarii, Estonii, na Litwie, Łotwie, w Słowacji i w Polsce. Od 2004 r., kiedy do Unii Europejskiej wstąpiło dziesięć nowych państw europejskich wzrost poziomu PKB per capita był najwyższy w tych samych krajach, w których odnotowano dynamiczny wzrost rozwoju gospodarczego od 2000 r. (tabela 1.).

Po 2004 r. najniższy wzrost gospodarczy z kolei miał miejsce w Grecji, Irlandii, Wielkiej Brytanii oraz we Włoszech i podobne tendencje w tych krajach utrzymywały się również po $2007 \mathrm{r}$.

Z kolei najwyższy przyrost PKB per capita liczony dla 2011 r. w porównaniu do sytuacji przed czterema laty miał miejsce w Polsce (przyrost o 27,17\%) oraz w nowych krajach członkowskich, w Bułgarii (o 18,09\%) i Rumunii (o 19,51\%).

${ }^{7}$ PPS (Purchasing Power Standard) to wymyślona waluta, za którą można kupić tyle samo w każdym kraju i dzięki temu wyklucza się ryzyko, że na wyniki mogą wpłynąć np. wahania kursu walut. 
Tabela 1. Produkt krajowy brutto według parytetu siły nabywczej na 1 mieszkańca (ceny bieżące) w latach 1995-2011 w dolarach międzynarodowych

\begin{tabular}{|c|c|c|c|c|c|c|c|c|}
\hline WYSZCZEGÓLNIENIE & 1995 & 2000 & 2004 & 2007 & 2011 & $\begin{array}{c}I_{z} \\
\text { DLA } 2011 R \\
2000=100\end{array}$ & $\begin{array}{c}I_{z} \\
\text { DLA } 2011 R \\
2004=100\end{array}$ & $\begin{array}{c}l_{z} \\
\text { DLA } 2011 R \\
2007=100\end{array}$ \\
\hline Austria & 23548 & 28909 & 32846 & 38074 & 42225 & 274,60 & 128,56 & 110,90 \\
\hline Belgia & 22501 & 27654 & 31177 & 35655 & 38605 & 262,45 & 123,82 & 108,28 \\
\hline Bułgaria & 5544 & 6226 & 8870 & 12366 & 14603 & 440,97 & 164,64 & 118,09 \\
\hline Cypr & 15441 & 19442 & 23208 & 28537 & 32087 & 310,27 & 138,26 & 112,44 \\
\hline Dania & 22999 & 28822 & 32281 & 37713 & 40983 & 267,32 & 126,96 & 108,67 \\
\hline Estonia & 6333 & 9883 & 14773 & 21594 & 21942 & 417,37 & 148,53 & 101,61 \\
\hline Finlandia & 18820 & 25674 & 29863 & 36167 & 38083 & 278,87 & 127,53 & 105,30 \\
\hline Francja & 20221 & 25172 & 28090 & 33025 & 34993 & 261,35 & 124,58 & 105,96 \\
\hline Grecja & 14559 & 18248 & 23861 & 27709 & 26948 & 277,63 & 112,94 & 97,25 \\
\hline Hiszpania & 16004 & 21315 & 25957 & 32230 & 32424 & 285,98 & 124,92 & 100,60 \\
\hline Irlandia & 17880 & 28925 & 36769 & 45506 & 41543 & 270,01 & 112,98 & 91,29 \\
\hline Litwa & 6215 & 8616 & 12968 & 18191 & 20374 & 444,57 & 157,11 & 112,00 \\
\hline Luksemburg & 38980 & 53662 & 64956 & 84525 & 89992 & 315,28 & 138,54 & 106,47 \\
\hline Łotwa & 5401 & 8040 & 11731 & 17178 & 17692 & 413,69 & 150,81 & 102,99 \\
\hline Malta & 15408 & 19044 & 19941 & 23527 & 27294 & 269,43 & 136,87 & 116,01 \\
\hline Niemcy & 22509 & 25761 & 29679 & 35557 & 39211 & 286,16 & 132,12 & 110,28 \\
\hline Polska & 7428 & 10516 & 13009 & 16757 & 21310 & 380,98 & 163,81 & 127,17 \\
\hline Portugalia & 13499 & 17797 & 19854 & 24201 & 25385 & 268,15 & 127,86 & 104,89 \\
\hline Republika Czeska & 13417 & 15549 & 20063 & 25429 & 26046 & 314,92 & 129,82 & 102,43 \\
\hline Rumunia & 5381 & 5663 & 8731 & 12688 & 15163 & 503,43 & 173,68 & 119,51 \\
\hline Słowacja & 8322 & 11008 & 14654 & 20873 & 24022 & 410,26 & 163,93 & 115,08 \\
\hline Stowenia & 13036 & 17558 & 22270 & 27228 & 27412 & 293,51 & 123,09 & 100,68 \\
\hline Szwecja & 21885 & 27957 & 32496 & 38478 & 41300 & 277,73 & 127,09 & 107,33 \\
\hline Węgry & 8997 & 11884 & 16188 & 18933 & 21610 & 341,88 & 133,50 & 114,14 \\
\hline Wielka Brytania & 19736 & 26070 & 31752 & 35735 & 35494 & 255,96 & 111,78 & 99,32 \\
\hline Włochy & 21239 & 25758 & 27528 & 32056 & 32928 & 240,33 & 119,61 & 102,72 \\
\hline $\bar{x}$ & 15588,5 & 20198,5 & 24365,9 & 29997,4 & 31910,4 & $x$ & $x$ & $x$ \\
\hline Vs & 50,50 & 51,42 & 47,92 & 47,33 & 45,81 & $x$ & $x$ & $x$ \\
\hline Min & 5381 & 5663 & 8731 & 12366 & 14603 & $x$ & $x$ & $x$ \\
\hline Max & 38980 & 53662 & 64956 & 84525 & 89992 & $x$ & $x$ & $x$ \\
\hline amplituda wahań & 7,24 & 9,48 & 7,44 & 6,84 & 6,16 & $x$ & $x$ & $x$ \\
\hline asymetria & 0,80 & 1,10 & 1,54 & 2,24 & 2,52 & $x$ & $x$ & $x$ \\
\hline
\end{tabular}

$\bar{X}$ - średnia; $V_{s}$ - współczynnik zmienności w \%, $l_{2}$ - wskaźnik dynamiki.

Źródło: obliczenia własne na podstawie World Development Indicators Database, Internet http://worldbank.org oraz Rachunków Narodowych, GUS, Warszawa, www.stat.gov.pl/gus/5840-11293_PLK_HTML.htm z dnia 6.02.2013 r. 
Pomiędzy krajami europejskimi oraz członkowskimi Unii Europejskiej występowały i nadal występują istotne dysproporcje w poziomie rozwoju gospodarczego, co znajduje swoje odzwierciedlenie w poziomie życia ludności. W 2000 roku obliczony współczynnik zmienności dla wszystkich krajów, które obecnie znajdują się w Unii Europejskiej wynosił ponad $V_{s}=50 \%$, a dla znajdujących się wówczas we wspólnocie europejskiej (EU15) był niższy, ale równie istotny i wynosił $V_{s}=30,93 \%$. Skala rozpiętości wartości GDP per capita wśród analizowanych krajów europejskich w 2000 r. wynosiła 9,48:1 (relacja pomiędzy Luksemburgiem a Rumunią). Z kolei w ówczesnej UE15 nie występowały aż takie dysproporcje i w 2000 r. relacja pomiędzy krajem o najwyższym przychodzie (Luksemburg) i o najniższym (Portugalia) wynosiła 2,98:1.

W ostatnich latach współczynnik zmienności pomiędzy analizowanymi krajami malał i w $2011 \mathrm{r}$. był na poziomie $V_{s}=45,81 \%$ co może świadczyć o pozytywnych tendencjach niwelowania zróżnicowań międzyregionalnych. Skala rozpiętości wartości GDP per capita wśród analizowanych krajów europejskich w 2011 r. zmniejszyła się i wynosiła w 2011 r. 6,2:1 (relacja pomiędzy Luksemburgiem i Bułgarią). Jednocześnie można zaobserwować wzrost wartości współczynnika asymetrii, co oznacza nasilającą się dodatnią asymetrię prawostronną. Dynamiczny wzrost tych wartości oznacza, że coraz więcej krajów charakteryzuje się niższą wartością GDP per capita w porównaniu do średniej dla krajów UE27.

\section{PORÓWNIANIE POZIOMU ŻYCIA W KRAJACH EUROPY I UNII EUROPEJSKIEJ NA PODSTAWIE GDP PER CAPITA I AIC PER CAPITA}

GDP per capita pomimo tego, że jest powszechnie stosowaną i generalnie akceptowaną miarą dobrobytu i poziomu życia ludności, jest krytykowane. Wymienia się, że produkt krajowy brutto nie uwzględnia produkcji nieewidencjonowanej, czyli tzw. szarej strefy oraz produkcji gospodarstw domowych przeznaczonych na własne potrzeby. Po za tym GDP nie uwzględnia faktu, iż nie cały wypracowany GDP trafia do obywateli w postaci bezpośredniej lub pośredniej, a część GDP transferowana jest w formie zysków za granicę. Istotnym zarzutem jest również brak uwzględniania wartości czasu wolnego lub wypoczynku, a także tzw. efektów zewnętrznych działalności przedsiębiorstw lub transportu. Istotną kwestią jest również fakt, że GDP per capita nie odzwierciedla zróżnicowania dochodów w społeczeństwie ani ich dystrybucji, co jest niezmiernie istotnym faktem w zakresie podejmowania decyzji strategicznych dotyczących polityki regionalnej każdego kraju. 
W związku z tym, że GDP per capita jest krytykowany i wymienia się szereg wad tego wskaźnika dobrobytu w grudniu 2012 roku przez Eurostat został opublikowany nowy alternatywny miernik poziomu życia ${ }^{8}$. Jest nim faktyczne spożycie indywidualne przypadające na jednego członka gospodarstwa domowego (Actual Indywidual Consumption - ACI per capita) wyrażone w tzw. standardach siły nabywczej, czyli sztucznej walucie eliminującej różnice cen między krajami. Uznano, że wskaźnik ten obejmuje spożycie gospodarstw domowych niezależnie od źródła finansowania, przez co bardziej niż GDP per capita nadaje się do porównań dobrobytu oraz opisywania sytuacji materialnej gospodarstw domowych.

Actual Indywidual Consumption opisuje wartość spożytych dóbr i usług przez gospodarstwa domowe, a nie efektów produkcji, które nie określają automatycznie poziomu życia. Wskaźnik ten został rekomendowany w raporcie opracowanym w 2009 roku $^{9}$ z inicjatywy prezydenta Francji Nicolasa Sarkozego, podważającego słuszność stosowania wskaźnika GDP do oceny poziomu życia.

Spożycie (final consumption expenditure) stanowią wydatki poniesione przez jednostki instytucjonalne na wyroby i usługi zużyte dla zaspokojenia bezpośrednich, indywidualnych i zbiorowych potrzeb społeczeństwa. Dzieli się na spożycie prywatne (tj. spożycie indywidualne w sektorze gospodarstw domowych oraz spożycie w sektorze instytucji niekomercyjnych) i spożycie publiczne (tj. spożycie indywidualne i ogólnospołeczne) ${ }^{10}$.

Spożycie indywidualne w sektorze gospodarstw domowych obejmuje wydatki poniesione przez ludność na zakup produktów (wyrobów i usług) wycenianych w cenach płaconych przez konsumentów, wyroby i usługi otrzymane jako dochód w naturze, wartość oszustw na podatku od towarów i usług (tzw. VAT fraud), wartość spożycia naturalnego, wartość usług mieszkaniowych, tj. czynsze umowne w odniesieniu do mieszkań użytkowanych przez właścicieli i najemców oraz zyski $z$ inwestowania składek otwartych funduszy emerytalnych $(\mathrm{OFE})^{11}$.

${ }^{8}$ GDP per capita varied by one to six across the Member States in 2011, Eurostat newsrelease, 180/2012 -13 December 2012.

9 J.E. Stiglitz, A. Sen, J. Fitoussi, Report by the Commission on the Measurement of Economic Performance and Social Progress, http://www.stiglitz-sen-fitoussi.fr/documents/rapport_anglais.pdf.

10 Pojęcia stosowane w badaniach statystycznych statystyki publicznej, GUS, Portal informacyjny, na podstawie rozporządzenia Rady (WE) nr 2223/96 z dnia 25 czerca 1996 r. w sprawie europejskiego systemu rachunków narodowych i regionalnych we Wspólnocie. Miejsce publikacji OJ L 31030.11.1996, p.1.

11 System Rachunków Narodowych (SRN) Tom II, GUS, Warszawa, Rozporządzenie Rady (WE) nr 2223/96 z dnia 25 czerwca 1996 r. w sprawie europejskiego systemu rachunków narodowych i regionalnych we Wspólnocie, Miejsce publikacji OJ L 31030.11.1996, p. 1. 
W porównaniach międzynarodowych spożycie indywidualne w sektorze gospodarstw domowych zaczyna być postrzegane jako odpowiednia miara poziomu życia. Po pierwsze, AIC obejmuje wydatki na towary i usługi, które zostały rzeczywiście zakupione i opłacone przez gospodarstwa domowe. Po drugie, spożycie indywidualne składa się z towarów i usług faktycznie wykorzystanych przez osoby, niezależnie od tego, czy są nabywane i opłacane przez gospodarstwa domowe, rząd, czy instytucje non-profit. Po trzecie, na wartość AIC nie mają wpływu różnice w organizacji niektórych ważnych konsumowanych usług, takich jak zdrowotnych czy edukacyjnych, które różnią się w wielu krajach (np. opłacane prze rząd w jednym kraju, a przez gospodarstwa domowe w drugim kraju ${ }^{12}$.

O problematycznej przydatności wskaźnika GDP per capita do porównań poziomu życia świadczą przypadki mniejszych krajów, takich jak Luksemburg czy Irlandia, gdzie relacja z zagranicą znacznie deformuje wielkość produktu krajowego brutto. W Luksemburgu zatrudnia się tysiące pracowników z trzech sąsiednich krajów: Niemiec, Francji i Belgii, którzy tworzą GDP tego kraju. Jednak osoby te nie są brane podczas przeliczania GDP na jednego mieszkańca. A przykładowo z Irlandii transferowane są zyski kapitału zagranicznego, które bezpośrednio nie zwiększają dobrobytu Irlandczyków ${ }^{13}$.

Luksemburg jest krajem o najwyższym poziomie GDP w Europie. Relacja tego wskaźnika do średniej unijnej (UE27) w 2011 roku wynosiła 271\%. Przeciwnie zaś wartość AIC per capita obniżyła się do 140\% w stosunku do średniej w UE27. Jedną z przyczyn może być udział transgranicznych pracowników do tworzenia wartości GDP, a ich wydatki na spożycie są rejestrowane $\mathrm{w}$ rachunkach narodowych w kraju ich zamieszkania. Przykładowo w przypadku Irlandii zastosowanie wskaźnika GDP (129\%) lokowało ten kraj w 2011 roku na trzeciej pozycji w Europie, a uwzględnienie AIC zepchnęło Irlandię o osiem pozycji w dól, na 11 miejsce w rankingu, tylko nieznacznie ponad średnią unijną, czyli do poziomu Włoch (101\%) (tabela 2.).

Analizując poziom życia w Polsce, należy stwierdzić, że faktyczne spożycie indywidualne per capita w Polsce na tle innych krajów europejskich prezentuje się zdecydowanie korzystniej niż GDP per capita. Wielkość tego wskaźnika wynosząca 69\% średniej unijnej przesuwa nasz kraj o dwie pozycje z klasyfikacji uwzględniającej GDP per capita (64\%), z 24 na 22 miejsce. Dzięki temu Polsce udało się wyprzedzić, poza Bułgarią, Rumunią i Łotwą, także Węgry (61\%) i Estonię (58\%). Można również zaobserwować, że różnica między

12 GDP per capita, consumptioon per bapita and price level indices, 2012, Statistics Explainned, European Commission, Eurostat, http://epp.eurostat.ec.europa.eu (13.02.2013 r.).

13 Nowa miara poziomu życia, Copyright 2012-2013, Biznes.pl, http://biznes.pl/wiadomości/ $\mathrm{kraj} /$ nowa-miara-poziomu-zycia,5381980, (02.01.2013 r.). 
Polską i Słowacją (70\%) czy Republiką Czeską (71\%) jest znikoma, w granicach błędu statystycznego. Biorąc pod uwagę fakt, że Republika Czeska przeżywa obecnie recesję (spadek PKB od 2008 roku), można oczekiwać, że już w 2013 roku zostanie zniwelowany dystans pomiędzy Polską a jej południowymi sąsiadami pod względem poziomu życia mieszkańców.

Tabela 2. Poziom życia w krajach UE27 na podstawie GDP per capita oraz AIC per capita w latach 2009$-2011($ EU27 $=100 \%)$

\begin{tabular}{|c|c|c|c|c|c|c|c|c|}
\hline \multirow[b]{2}{*}{ WYSZCZEGÓLNIENIE } & \multicolumn{4}{|c|}{ GDP PER CAPITA } & \multicolumn{4}{|c|}{ AIC PER CAPITA } \\
\hline & 2009 & 2010 & 2011 & $\begin{array}{c}\text { LOKATA } \\
\text { w } 2011 \mathrm{R}\end{array}$ & 2009 & 2010 & 2011 & $\begin{array}{c}\text { LOKATA } \\
\text { W } 2011 \mathrm{R} .\end{array}$ \\
\hline EU27 & 100 & 100 & 100 & & 100 & 100 & 100 & \\
\hline Strefa euro (EA17) & 109 & 108 & 108 & & 107 & 107 & 107 & \\
\hline Luksemburg & 255 & 267 & 271 & 1 & 144 & 141 & 140 & 1 \\
\hline Holandia & 132 & 131 & 131 & 2 & 118 & 114 & 113 & 6 \\
\hline Irlandia & 130 & 129 & 129 & 3 & 103 & 103 & 101 & 11 \\
\hline Austria & 125 & 127 & 129 & 4 & 116 & 118 & 119 & 3 \\
\hline Szwecja & 120 & 124 & 127 & 5 & 116 & 114 & 116 & 5 \\
\hline Dania & 123 & 128 & 125 & 6 & 116 & 116 & 113 & 7 \\
\hline Niemcy & 115 & 119 & 121 & 7 & 115 & 117 & 120 & 2 \\
\hline Belgia & 118 & 119 & 119 & 8 & 109 & 111 & 111 & 10 \\
\hline Finlandia & 114 & 113 & 114 & 9 & 110 & 111 & 112 & 9 \\
\hline Wielka Brytania & 111 & 111 & 109 & 10 & 121 & 120 & 118 & 4 \\
\hline Francja & 109 & 108 & 108 & 11 & 113 & 113 & 113 & 8 \\
\hline Włochy & 104 & 101 & 100 & 12 & 103 & 102 & 101 & 12 \\
\hline Hiszpania & 103 & 99 & 98 & 13 & 96 & 95 & 94 & 14 \\
\hline Cypr & 100 & 97 & 94 & 14 & 102 & 99 & 98 & 13 \\
\hline Malta & 83 & 85 & 85 & 15 & 85 & 83 & 84 & 16 \\
\hline Stowenia & 87 & 84 & 84 & 16 & 81 & 80 & 81 & 17 \\
\hline Republika Czeska & 83 & 80 & 80 & 17 & 73 & 71 & 71 & 19 \\
\hline Grecja & 94 & 87 & 79 & 18 & 104 & 97 & 91 & 15 \\
\hline Portugalia & 80 & 80 & 77 & 19 & 83 & 84 & 81 & 18 \\
\hline Słowacja & 73 & 73 & 73 & 20 & 72 & 71 & 70 & 20 \\
\hline Estonia & 63 & 63 & 67 & 21 & 58 & 56 & 58 & 24 \\
\hline Litwa & 55 & 57 & 66 & 22 & 63 & 61 & 70 & 21 \\
\hline Węgry & 65 & 65 & 66 & 23 & 62 & 60 & 61 & 23 \\
\hline Polska & 61 & 63 & 64 & 24 & 64 & 67 & 69 & 22 \\
\hline Łotwa & 54 & 54 & 58 & 25 & 52 & 53 & 57 & 25 \\
\hline Rumunia & 47 & 47 & 49 & 26 & 46 & 46 & 47 & 26 \\
\hline Bułgaria & 44 & 44 & 46 & 27 & 43 & 43 & 45 & 27 \\
\hline
\end{tabular}

Źródło: obliczenia własne na podstawie GDP per capita varied by one to six across the Member States in 2011, Eurostat newsrelease, 180/2012-13 December 2012; GDP per capita, consumption per capita and price level indices, http://epp.eurostat.ec.europa.eu (14.01.2013 r.). 
Tabela 3. Poziom życia w pozostałych krajach Europy na podstawie GDP per capita oraz AIC per capita w latach 2009-2011 (EU27=100\%)

\begin{tabular}{|c|c|c|c|c|c|c|}
\hline \multirow{2}{*}{ WYszCZEGólNIENIE } & \multicolumn{3}{|c|}{ GDP PER CAPITA } & \multicolumn{3}{c|}{ AIC PER CAPITA } \\
\cline { 2 - 7 } & 2009 & 2010 & 2011 & 2009 & 2010 & 2011 \\
\hline EU27 & 100 & 100 & 100 & 100 & 100 & 100 \\
\hline Norwegia & 177 & 181 & 186 & 134 & 136 & 135 \\
\hline Szwajcaria & 150 & 154 & 157 & 128 & 129 & 130 \\
\hline Islandia & 120 & 112 & 111 & 111 & 106 & 107 \\
\hline Chorwacja & 62 & 59 & 61 & 58 & 57 & 59 \\
\hline Turcja & 46 & 50 & 52 & 51 & 54 & 57 \\
\hline Czarnogóra & 41 & 42 & 42 & 50 & 52 & 53 \\
\hline Była Jugosłowiańska Republika Macedonii & 36 & 36 & 35 & 41 & 40 & 40 \\
\hline Serbia & 36 & 35 & 35 & 44 & 44 & 43 \\
\hline Albania & 28 & 27 & 30 & 32 & 30 & 34 \\
\hline Bośnia i Hercegowina & 31 & 30 & 30 & 37 & 36 & 36 \\
\hline
\end{tabular}

Źródło: obliczenia własne na podstawie GDP per capita varied by one to six across the Member States in 2011, Eurostat newsrelease, 180/2012-13 December 2012; GDP per capita, consumption per capita and price level indices, http://epp.eurostat.ec.europa.eu (z dnia 14.01.2013 r.).

Spośród krajów, które nie znajdują się w Unii Europejskiej najlepiej wypada Norwegial której wartość GDP per capita w 2011 r. wynosiła 186\%, a AIC per capita 135\% średniej UE27. Wysokie wskaźniki można również zaobserwować dla Szwajcarii (157\% i 135\% średniej UE27) i Islandii (111\% i 107\% średniej UE27). Zaskoczeniem może być wynik Chorwacji (PKB per capita wynosi $61 \%$, a AIC per capita 59\% średniej UE27), który wskazuje, że przeciętny mieszkaniec Chorwacji jest na tym samym poziomie zamożności co mieszkaniec Polski. Najbiedniejsi w Europie są mieszkańcy Albanii (30\% i 34\% średniej UE27) oraz Bośni i Hercegowiny (30\% i 36\% średniej UE27) (tabela 3.).

$\mathrm{Na}$ podstawie porównania wartości GDP per capita oraz AIC per capita można zaobserwować, że poziom AIC przypadający na jednego mieszkańca kraju jest bardziej jednolity. Potwierdzają to obliczone współczynniki zmienności oraz amplituda wahań. Otóż w latach 2009-2011 współczynnik zmienności dla GDP per capita w UE-27 oscylował w granicach $V_{s}=42-44 \%$, a dla AIC per capita $\mathrm{w}$ granicach $V_{s}=28-29 \%$. Na znacznie wyższym poziomie jest zróżnicowanie regionalne we wszystkich analizowanych krajach europejskich (dodatkowo Islandia, Norwegia, Szwajcaria, Chorwacja, Była Jugosłowiańska Republika Macedonii, Czarnogóra, Serbia i Turcja). Współczynnik zmienności dla GDP per capita wynosił w latach 2009-2011 $V_{s}=51-52 \%$, a dla AIC per capita oscylował w granicach $V_{s}=36-37 \%$. Pozytywnym aspektem jest fakt, iż w 2011 roku zróżnicowanie pomiędzy krajami zmalało. Prawie o jeden punkt 
procentowy obniżył się współczynnik zmienności obliczony dla AIC per capita (tabela 4.).

Tabela 4. Współczynniki opisujące zróżnicowanie krajów pod względem GDP per capita oraz AIC per capita (UE27 $=100)$

\begin{tabular}{|c|c|c|c|c|c|c|c|}
\hline \multirow{2}{*}{ WYszczegóLnienIE } & \multicolumn{3}{|c|}{ GDP PER CAPITA } & \multicolumn{3}{c|}{ AIC PER CAPITA } \\
\cline { 2 - 8 } & 2009 & 2010 & 2011 & 2009 & 2010 & 2011 \\
\hline \multicolumn{7}{|c|}{ UE-27 } \\
\hline Współczynnik zmienności $V_{s}$ W \% & 42,18 & 44,08 & 43,89 & 29,44 & 29,49 & 28,25 \\
\hline Amplituda wahań & 5,8 & 6,07 & 5,89 & 3,35 & 3,28 & 3,11 \\
\hline Asymetria & 1,99 & 2,21 & 2,4 & $-0,24$ & $-0,24$ & $-0,17$ \\
\hline UE-27 i pozostałe kraje Europy (wymienione w tabeli 3.) \\
\hline Współczynnik zmienności $V_{s}$ w \% & 50,55 & 52,19 & 52,09 & 37,46 & 37,56 & 36,31 \\
\hline Amplituda wahań & 9,11 & 9,89 & 9,03 & 4,5 & 4,7 & 4,12 \\
\hline Asymetria & 1,23 & 1,43 & 1,53 & $-0,07$ & $-0,05$ & $-0,03$ \\
\hline
\end{tabular}

Źródło: obliczenia własne na podstawie GDP per capita varied by one to six across the Member States in 2011. Eurostat newsrelease, 180/2012 -13 December 2012; GDP per capita, consumption per capita and price level indices. http://epp.eurostat.ec.europa.eu (z dnia 14.01.2013 r.).

Jednocześnie można zaobserwować, że dystans pomiędzy Luksemburgiem a Bułgarią (biorąc pod uwagę UE27) oraz Luksemburgiem a Albanią (wszystkie analizowane kraje europejskie) jest o wiele większy pod kątem produktu krajowego brutto przypadającego na jednego mieszkańca (amplituda wahań około 9:1) niż spożycia indywidualnego w gospodarstwach domowych (około 4:1). Zatem można stwierdzić, że poziom AIC per capita jest bardziej jednolity w porównaniu do GDP per capita, jakkolwiek nadal istnieją znaczne dysproporcje pomiędzy wszystkimi państwami europejskimi oraz będącymi we wspólnocie UE27 (tabela 4.).

\section{ZAKOŃCZENIE}

Możliwość rozwoju gospodarczego i społecznego wywarła istotny wpływ na zmiany ekonomiczne i społeczne w krajach europejskich. Dynamiczny wzrost zmian gospodarczych ma związek z akcesją krajów do Unii Europejskiej, która miała miejsce w różnych latach dla różnych krajów. Rozwój społeczno-ekonomiczny znalazł swoje odzwierciedlenie we wzroście poziomu życia ludności i ich dobrobytu. Aspekty te mierzone są za pomocą wskaźników między innymi takich jak produkt krajowy brutto, a także faktyczne spożycie indywidualne w przeliczeniu na jednego mieszkańca kraju. 
Wartość omawianych w artykule wskaźników GDP per capita oraz AIC per capita we wszystkich krajach europejskich dynamicznie wzrasta, przy czym wzrost jest tym większy im kraj później stał się członkiem Unii Europejskiej.

Zróżnicowanie krajów pod względem wytwarzania produktu krajowego brutto jest znacznie wyższe niż w zakresie spożycia indywidualnego, skąd też wskaźnik drugi prezentuje się znacznie korzystniej niż GDP per capita.

W tworzeniu wartości faktycznego spożycia indywidualnego decydujące znaczenie mają wydatki samych gospodarstw domowych, które we wszystkich krajach dynamicznie rosną. Konsekwencją dużych wydatków jest niższa stopa oszczędności gospodarstw domowych oraz towarzysząca jej niska stopa inwestycji w skali kraju. Inaczej mówiąc, niska skłonność do oszczędzania gospodarstw domowych oraz niska skłonność do inwestycji przedsiębiorstw przyczyniają się do stosunkowo wysokiej wartości wskaźnika zasięgu zagrożenia ubóstwem ${ }^{14}$. Patrząc na sytuację w krajach europejskich z dłuższej perspektywy można stwierdzić, że wysoka stopa konsumpcji indywidualnej poprawia obecne warunki życia, jednakże zaniedbywanie wydatków inwestycyjnych może w konsekwencji narazić kraj na niższe tempo wzrostu gospodarczego w przyszłości. Oznacza to także mniejsze możliwości zwiększania w przyszłości poziomu życia.

\section{BIBLIOGRAFIA}

Bywalec Cz., Rudnicki L., Konsumpcja, PWE, Warszawa 2002.

GDP per capita, consumption per capita and price level indices, Statistics Explainned, European Commission, Eurostat, 2012, http://epp.eurostat.ec.europa.eu (13.02.2013 r.).

GDP per capita varied by one to six across the Member States in 2011, Eurostat Newsrelease, 180/2012 -13 December 2012.

Gutkowska K., Murawska A., Regionalne zróżnicowanie poziomu i jakości życia Polakóww, „Handel Wewnętrzny”, Konsumpcja a rozwoój regionów, IBRKiK, Warszawa, styczeń-luty 2011.

Kramer J., Przestrzenna struktura konsumpcji w Polsce, PWN, Warszawa 1980.

Murawska A., Rozwój spoteczno-ekonomiczny a poziom życia w gospodarstwach domowych w Polsce, praca doktorska, SGGW, Warszawa, (maszynopis niepublikowany), 2009.

${ }_{14}$ T. Panek, Wskaźniki ubóstwa w ujęciu wielowymiarowym, „Wiadomości Statystyczne”, Nr 12, GUS i PTS, Warszawa, 2009. 
Narkiewicz J., Regionalne zróżnicowanie poziomu życia ludności, Wiadomości Statystyczne, nr 12, 1996.

Nowa miara poziomu życia, Copyright 2012-2013, Biznes.pl, http://biznes.pl/wiadomości/kraj/nowa-miara-poziomu-zycia,5381980, (02.01.2013 r.).

Panek T., Wskaźniki ubóstwa w ujęciu wielowymiarowym, „Wiadomości Statystyczne”, nr 12, GUS i PTS, Warszawa, 2009.

Pojęcia stosowane w badaniach statystycznych statystyki publicznej, GUS, Portal informacyjny, na podstawie rozporządzenia Rady (WE) nr 2223/96 z dnia 25 czerwca 1996 r. w sprawie europejskiego systemu rachunków narodowych i regionalnych we Wspólnocie. Miejsce publikacji OJ L 31030.11 .1996 p.1.

Rachunki Narodowe, GUS, Warszawa, www.stat.gov.pl/gus/5840-11293_PLK_ HTML.htm (6.02.2013 r.).

Stiglitz J.E., Sen A., Fitoussi J. P., Report by the Commission on the Measurement of Economic Performance and Social Progress, 2009, http://www.stiglitz-sen-fitoussi.fr/documents/rapport_anglais.pdf (6.02.2013 r.).

System Rachunków Narodowych (SRN) Tom II, GUS, Warszawa, Rozporzadzenie Rady (WE) nr 2223/96 z dnia 25 czerwca 1996 r. w sprawie europejskiego systemu rachunków narodowych i regionalnych we Wspólnocie, Miejsce publikacji OJ L 31030.11.1996 p. 1.

World Development Indicators Database, Internet http://worldbank.org (6.02.2013 r.). 
